\begin{tabular}{lrr} 
Jurnal Pendidikan Dasar Perkhasa & \\
http://jurnal.stkippersada.ac.id/jurnal/index.php/JPDP/ & P-ISSN 2461-078X \\
& & E-ISSN 2654-783X \\
& JPDP 7 (1) (2021) 25-34 & DoI: 10.31932/jpdp.v7i1.1088 \\
\hline
\end{tabular}

\title{
META ANALISIS PENERAPAN MODEL PEMBELAJARAN TWO STAY TWO STRAY TERHADAP PENINGKATAN HASIL BELAJAR IPA SISWA SEKOLAH DASAR
}

\author{
Veronica Venny Kusumawati*1, Firosalia Kristin ${ }^{2}$ \\ 1,2Program Studi Pendidikan Guru Sekolah Dasar, Universitas Kristen Satya Wacana
}

Diterima: 4 April 2021. Dipublikasi: 26 April 2021.

\begin{abstract}
This study aims to re-analyze the application of the Two Stay Two Stray model in improving the learning outcomes of elementary school students. This study uses a meta-analysis method. The author begins the research by searching for relevant journals to facilitate the author in the data collection process. The data is obtained through searching online journals through google scholar or google academia by writing the keywords Two Stay Two Stray, science learning outcomes, and elementary school. From the search conducted, the researcher obtained 25 journals and then the researcher chose 16 journals that match the author's criteria. The data that has been obtained will be processed again using quantitative methods. Based on the results of the analysis by applying the Two Stay Two Stray learning model in learning, it shows that this model can improve students' science learning outcomes with the lowest average value of $0.080 \%$ and the highest average value of $51.24 \%$. The implementation of Two Stay Two Stray greatly affects the learning outcomes of elementary school students. In addition, students also have different habits in the teaching and learning process because they are required to think more critically and be open to friends. It can also improve students' understanding of the subject matter easily during the learning process.
\end{abstract}

Keywords: Model Two Stay Two Stray, Science learning outcomes, Primary Schools, Meta-analysis.

Abstrak. Penelitian ini bertujuan untuk menganalisis kembali penerapan pembelajaran model Two Stay Two Stray dalam meningkatkan hasil belajar siswa sekolah dasar. Penelitian ini merupakan penelitian dengan menggunakan metode meta analisis. Penulis mengawali penelitian dengan cara mencari jurnal yang relevan untuk mempermudah penulis dalam proses pengumpulan data. Data diperoleh melalui penelusuran jurnal-jurnal online melalui google scholar atau google academia dengan menuliskan kata kunci Two Stay Two Stray, hasil belajar IPA, dan sekolah dasar. Dari penelusuran yang dilakukan peneliti memperoleh 25 jurnal kemudian peneliti memilih 16 jurnal yang sesuai kriteria penulis. Data-data yang sudah diperoleh akan diolah kembali menggunakkan metode kuantitatif. Berdasarkan hasil analisis dengan menerapkan model pembelajaran Two Stay Two Stray dalam pembelajaran menunjukkan bahwa model tersebut dapat meningkatkan hasil belajar IPA siswa dengan rata-rata nilai paling rendah $0,080 \%$ dan rata-rata nilai paling tinggi 51,24\%. Penerapan Two Stay Two Stray sangat berpengaruh terhadap hasil belajar siswa sekolah dasar. Selain itu siswa juga memiliki kebiasaan yang berbeda dalam proses belajar mengajar karena dituntut untuk berpikir lebih kritis dan bersikap terbuka terhadap teman. Hal tersebut juga dapat meningkatkan pemahaman siswa terhadap materi pelajaran dengan mudah selama proses pembelajaran.

Kata kunci: Model Two Stay Two Stray, Hasil Belajar IPA, SD, Meta Analisis 


\section{Pendahuluan}

Pendidikan merupakan hal yang dianggap sangat penting dalam kehidupan. Pendidikan memiliki 3 ranah yaitu kognitif, afektif, dan psikomotor. Adanya tiga ranah tersebut, menunjukkan bahwa proses pembelajaran di kelas akan menjadi lebih fokus pada kegiatan belajar peserta didik. Sumber belajar siswa bukan hanya melalui guru, melainkan dapat melalui berbagai sumber. Oleh karena itu pendidikan hendaknya dikelola, baik secara kualitas maupun kuantitas untuk menghasilkan mutu pendidikan yang lebih baik melalui hasil belajar siswa.

Menurut Susanto (2013:4) belajar merupakan suatu aktivitas mental yang berlangsung dalam interaksi aktif antara seseorang dengan lingkungan, dan menghasilkan perubahan-perubahan dalam pengetahuan, pemahaman keterampilan, dan nilai sikap yang bersifat relatif konstan. Hasil belajar seringkali digunakan sebagai ukuran untuk mengetahui seberapa jauh seseorang menguasai bahan yang sudah ia pelajari. Untuk mengaktualisasikan hasil belajar tersebut diperlukan serangkaian pengukuran menggunakan alat evaluasi yang baik dan memenuhi syarat.

Kegiatan belajar mengajar merupakan kegiatan yang dilakukan oleh peserta didik selama kegiatan pembelajaran. Guru dapat merancang pembelajaran inovatif yang disesuaikan dengan karakteristik siswa. Salah satu model pembelajaran yang dapat digunakan untuk menunjang pembelajaran yang inovatif yaitu model pembelajaran Two Stay Two Stray. Soekamto dalam Trianto (2010:22) menyatakan bahwa model pembelajaran adalah suatu susunan konseptual yang melukiskan urutan yang sistematis dalam mengarahkankan pengalaman belajar guna mencapai tujuan belajar tertentu, dan berguna untuk pedoman para penyusun dan pengajar dalam merencanakan pembelajaran. Berdasarkan pendapat tersebut dapat dilihat bahwa model Two Stay Two Stray dapat memfasilitasi siswa untuk berperan aktif dan saling terbuka terhadap teman dalam kelas selama proses belajar mengajar berlangsung.

Pembelajaran IPA di sekolah dasar merupakan pondasi awal untuk menciptakan siswa yang memiliki 
pengetahuan, keterampilan dan sikap ilmiah. Pembelajaran IPA berkaitan dengan cara mencari tahu tentang alam secara sistematis dan terarah, sehingga IPA bukan hanya penguasaan tentang pengetahuan yang berupa fakta-fakta dan konsepkonsep saja melainkan juga proses penyelidikan dan penemuan. Jika dalam pembelajaran IPA bisa menerapkan prinsip-prinsip pembelajaran, maka pembelajaran IPA dapat berjalan secara maksimal dan dapat meningkatkan hasil belajar siswa pada muatan pembelajaran IPA Sekolah Dasar.

Hasil dari survey penelitian tentang penerapan model pembelajaran Two Stay Two Stray terhadap hasil belajar siswa sekolah dasar, penulis mengambil beberapa sampel artikel dalam jurnal-jurnal online dengan latar belakang penelitian yaitu meningaktan hasil belajar siswa. Karena model pembelajaran Two Stay Two Stray tidak hanya terfokus pada kelompok sendiri, melainkan dapat terfokus juga pada kelompok lain melalui diskusi. Berdiskusi yang dimaksudkan dalam hal ini dimana semua kelompok diberi kesempatan untuk mengembangkan hasil yang telah didiskusikan dengan kelompok lain, sehingga setiap kelompok diberi kesempatan untuk membagikan hasil diskusinya kepada kelompok lain dan dapat meningkatakan kemampuan pembelajaran dalam mengemukakan pendapat serta dapat menghargai pendapat orang lain. Dapat dilihat terjadinya peningkatan hasil belajar dengan berbantuan model pembelajaran Two Stay Two Stray dengan rentang peningkatan yang berbeda-beda. Berdasarkan dari hasil penelitian dapat dibuktikan bahwa penggunaan model pembelajaran Two Stay Two Stray yang dapat mempengaruhi peningkatan hasil belajar IPA siswa.

Penulis bermaksud untuk mendalami lebih lanjut hasil-hasil penelitian yang sudah ada selama ini guna menunjukkan peran model pembelajaran Two Stay Two Stray dalam pembelajaran untuk meningkatkan hasil belajar IPA peserta didik. Guru dapat menggunakan model pembelajaran Two Stay Two Stray untuk meningkatkan hasil belajar siswa sekolah dasar. Melalui penggunaan model pembelajaran Two Stay Two 
Stray siswa benar-benar terlibat langsung aktif serta mampu bersikap terbuka terhadap teman dalam pembelajaran yang berlangsung. Proses tersebut dapat membangkitkan motivasi siswa yang sangat berpengaruh pada peningkatan hasil belajar siswa.

Berdasarkan masalah-masalah yang mengarah pada hasil belajar IPA siswa yang masih belum maksimal, maka fokus pada penelitian ini guna menganalisis kembali apakah penerapan model pembelajaran Two Stay Two Stray dapat meningkatkan hasil belajar IPA siswa sekolah dasar? Kerangka pada penulisan artikel ini adalah pendahuluan, metode penelitian, hasil dan pembahasan.

\section{Metode}

Metode penelitian yang digunakan dalam penelitian ini adalah meta analisis. Menurut Sriawan \& Utami dalam Mansyur (2017:73) Meta analisis adalah suatu teknik yang digunakan untuk merangkum temuan dua penelitian atau lebih dengan tujuan untuk menggabungkan, meninjau dan meringkas penelitian sebelumnya. Secara sederhana dapat disimpulkan bahwa meta analisis yaitu pengkajian ulang terhadap hasilhasil penelitian sejenis yang sudah ada. Meta analisis adalah sebuah cara untuk merangkum hasil penelitian secara kuantitatif. Data yang dikumpulkan dalam penelitian ini dilakukan dengan penelusuran jurnaljurnal pada media elektronik. Jurnal dicari melalui Google Academia dan Google Scholaria dengan mencantumkan kata kunci model pembelajaran Two Stay Two Stray, Hasil Belajar IPA, Sekolah Dasar. Hasil pencarian yang didapatkan adalah 25 jurnal, kemudian penulis memutuskan 16 hasil penelitian yang relevan untuk digunakan dalam penelitian ini yang sesuai kriteria yang penulis tetapkan yaitu, memiliki data berupa rata-rata nilai sebelum dan sesudah mendapat perlakuan. Seluruh hasil data dari jurnal yang dikaji ulang oleh penulis merupakan hasil penelitian Eksperimen, maka dapat diperoleh data nilai sebelum dan sesudah perlakuan. Penulis melaksanakan pengolahan data dengan menerapkan metode pembandingan guna mengetahui dampak dari penerapan model pembelajaran Two Stay Two Stray yang mengarah pada selisih skor 
hasil belajar IPA siswa sebelum dan sesudah tindakan.

\section{Hasil dan Pembahasan}

Berdasarkan pencarian di Google Scholaria didapat 25 artikel yang sesuai dengan judul yang akan diteliti dan hanya dipilih 16 yang relevan dan sesuai dengan kriteria. 16 artikel yang dipilih memiliki data hasil penelitian yang lengkap sesuai dengan kriteria yang dibutuhkan penulis untuk diolah. Data 16 artikel dapat dilihat pada Tabel 1 sebagai berikut.

Tabel 1. Peningkatan Hasil Belajar

\begin{tabular}{|c|c|c|c|c|c|c|}
\hline \multirow[t]{2}{*}{ No } & \multirow[t]{2}{*}{ Judul Penelitian } & \multirow[t]{2}{*}{ Peneliti } & \multicolumn{4}{|c|}{ Peningkatan Hasil Belajar } \\
\hline & & & Sebelum & Sesudah & Gain & Gain\% \\
\hline 1. & $\begin{array}{l}\text { Pengaruh Model } \\
\text { Pembelajaran Kooperatif } \\
\text { Tipe TSTS melalui Lesson } \\
\text { Study terhadap Hasil } \\
\text { Belajar IPA }\end{array}$ & $\begin{array}{l}\text { Sidabutar dan } \\
\text { Dharsana }\end{array}$ & 16,82 & 21,59 & 4,77 & 28,35 \\
\hline 2. & $\begin{array}{l}\text { Pengaruh Model } \\
\text { Pembelajaran Kooperatif } \\
\text { TSTS Berbantuan Mind } \\
\text { Mapping terhadap Hasil } \\
\text { Belajar IPA }\end{array}$ & $\begin{array}{l}\text { Juniantari dan } \\
\text { Kusmariyatni }\end{array}$ & 19,25 & 24,78 & 5,53 & 28,72 \\
\hline 3. & $\begin{array}{l}\text { Model TSTS Berbantuan } \\
\text { Peta Konsep Berpengaruh } \\
\text { terhadap Hasil Belajar IPA } \\
\text { Kelas V }\end{array}$ & $\begin{array}{l}\text { Dewi, Putra, } \\
\text { dan Abadi }\end{array}$ & 62,12 & 81,54 & 19,42 & 31,26 \\
\hline 4. & $\begin{array}{l}\text { Pengaruh Model } \\
\text { Pembelajaran Two Stay Two } \\
\text { Stray Berbantuan Media } \\
\text { Visual terhadap Hasil } \\
\text { Belajar IPA Siswa } \\
\end{array}$ & $\begin{array}{l}\text { Diarsa, Murda, } \\
\text { Dharmayanti }\end{array}$ & 15,45 & 21,9 & 6,45 & 41,74 \\
\hline 5. & $\begin{array}{l}\text { Pengaruh Model } \\
\text { Pembelajaran Two Stay Two } \\
\text { Stray terhadap Hasil Belajar } \\
\text { IPA }\end{array}$ & $\begin{array}{l}\text { Dumaini, } \\
\text { Suarjana, dan } \\
\text { Dibia }\end{array}$ & 17,23 & 24,11 & 6,88 & 39,93 \\
\hline 6. & $\begin{array}{l}\text { Pengaruh Model } \\
\text { Pembelajaran Two Stay Two } \\
\text { Stray terhadap Hasil Belajar } \\
\text { IPA pada Siswa Kelas IV }\end{array}$ & $\begin{array}{l}\text { Fitrianingrum } \\
\text { dan Zuhdi }\end{array}$ & 66,05 & 83,47 & 17,42 & 26,37 \\
\hline 7. & $\begin{array}{l}\text { Pengaruh Model Kooperatif } \\
\text { Two Stay Two Stray } \\
\text { terhadap Hasil Belajar IPA }\end{array}$ & $\begin{array}{l}\text { Rediarta, } \\
\text { Sudarma, dan } \\
\text { Murda }\end{array}$ & 24,08 & 28,11 & 4,03 & 16,73 \\
\hline 8. & $\begin{array}{l}\text { Pengaruh Model } \\
\text { Pembelajaran Kooperatif } \\
\text { TSTS terhadap Hasil Belajar } \\
\text { Siswa di SD }\end{array}$ & $\begin{array}{l}\text { Azizah dan } \\
\text { Mintohari }\end{array}$ & 70,69 & 82,19 & 11,5 & 16,26 \\
\hline 9. & $\begin{array}{l}\text { Pengaruh Model } \\
\text { Pembelajaran Kooperatif } \\
\text { Two Stay Two Stray } \\
\text { Terhadap } \\
\text { Hasil Belajar IPA }\end{array}$ & $\begin{array}{l}\text { Dewi, } \\
\text { Margunayasa, } \\
\text { Kusmariyatni }\end{array}$ & 15,61 & 23,61 & 8 & 51,24 \\
\hline
\end{tabular}




\begin{tabular}{|c|c|c|c|c|c|c|}
\hline 10. & $\begin{array}{l}\text { Keefektifan Model TSTS } \\
\text { terhadap Hasil Belajar pada } \\
\text { Mata Pelajaran IPA Siswa } \\
\text { Kelas V SD }\end{array}$ & $\begin{array}{l}\text { Khoirul } \\
\text { Amanuan }\end{array}$ & 29,6 & 74,9 & 45,3 & 1,53 \\
\hline 11. & $\begin{array}{l}\text { Pembelajaran Kooperatif } \\
\text { Tipe TSTS Berbantuan Peta } \\
\text { Pikiran untuk } \\
\text { Meningkatkan Hasil Belajar } \\
\text { IPA melalui Lesson Study". }\end{array}$ & $\begin{array}{l}\text { Karlina, } \\
\text { Dharsana, dan } \\
\text { Kusmariyatni }\end{array}$ & 15,29 & 19,85 & 4.56 & 29,82 \\
\hline 12. & $\begin{array}{l}\text { Penggunaan Model } \\
\text { Pembelajaran Two Stay Two } \\
\text { Stray dalam Pembelajaran } \\
\text { IPA di Sekolah Dasar }\end{array}$ & $\begin{array}{l}\text { Zairmi, Fitria, } \\
\text { dan Amini }\end{array}$ & 74,8 & 86,25 & 11,45 & 15,30 \\
\hline 13. & $\begin{array}{l}\text { Pengaruh Penerapan Model } \\
\text { Pembelajaran Kooperatif } \\
\text { Tipe TSTS terhadap } \\
\text { Aktivitas dan Hasil Belajar } \\
\text { Siswa tentang IPA di Kelas } \\
\text { VI SD Impres Palupi }\end{array}$ & Sitilin Kumape & 46,8 & 54,03 & 7,23 & 15,44 \\
\hline 14. & $\begin{array}{l}\text { Pengaruh Model } \\
\text { Pembelajaran TSTS } \\
\text { Berbasis Masalah terhadap } \\
\text { Hasil Belajar IPA Siswa } \\
\text { Kelas V }\end{array}$ & $\begin{array}{l}\text { Prasatya, } \\
\text { Murda, dan } \\
\text { Arini }\end{array}$ & 15,85 & 23,00 & 7,15 & 45,11 \\
\hline 15. & $\begin{array}{l}\text { Pengaruh Model TSTS } \\
\text { melalui Lesson Study } \\
\text { terhadap Hasil Belajar IPA }\end{array}$ & $\begin{array}{l}\text { Harta, } \\
\text { Dharsana, dan } \\
\text { Renda }\end{array}$ & 20,08 & 24,03 & 3,95 & 19,67 \\
\hline 16. & $\begin{array}{l}\text { Pengaruh Metode } \\
\text { Pembelajaran Kooperatif } \\
\text { Two Stay Two Stray } \\
\text { Terhadap Hasil Belajar IPA } \\
\text { Kelas IV }\end{array}$ & $\begin{array}{l}\text { Giantri, Wiyasa, } \\
\text { dan Suadnyana }\end{array}$ & 68,05 & 73,50 & 5,45 & 0,080 \\
\hline \multicolumn{3}{|c|}{$\begin{array}{l}\text { Rata-rata Pembelajaran Menggunakan Two Stay Two } \\
\text { Stray }\end{array}$} & 36,11 & 46,67 & 10,56 & 25,47 \\
\hline
\end{tabular}

Dari hasil penelitian, dapat bahwa penggunaan model disimpulkan bahwa dengan pembelajaran Two Stay Two Stray menggunakan model pembelajaran dapat meningkatkan hasil belajar IPA, Two Stay Two Stray dapat mulai dari hasil nilai rata-rata yang memberikan dampak positif terhadap peningkatan hasil belajar siswa. Dari terendah $0,080 \%$ sampai nilai ratarata yang tertinggi 51,24\%. Penerapan 16 sampel artikel masing-masing menunjukkan besarnya pengaruh penggunaan model pembelajaran Two Stay Two Stray. Berdasarkan data yang terdapat pada tabel 1 menunjukkan model Two Stay Two Stray pada pembelajaran adalah salah satu solusi yang efektif dan dapat digunakan guru untuk meningkatkan hasil belajar siswa. Dapat dikatakan bahwa model 
pembelajaran Two Stay Two Stray dapat meningkatkan hasil belajar siswa dikarenakan model pembelajaran tersebut dapat menghasilkan proses pembelajaran menjadi lebih menyenangkan dan tidak membosankan. Berdasarkan pendapat Warsito dalam Depdiknas (2012:125) mengemukakan bahwa hasil dari kegiatan belajar ditandai dengan adanya perubahan perilaku ke arah positif yang relatif permanen pada diri orang yang telah belajar. Sehubungan dengan pendapat tersebut maka dapat disimpulkan bahwa siswa dapat dikatakan berhasil apabila pada hasil belajar mengalami peningkatan setelah diterapkannya model pembelajaran Two Stay Two Stray.

Hasil belajar memiliki peranan yang sangat penting dalam pencapaian atau sebagai tolak ukur selama belajar di sekolah. Siswa yang memiliki hasil belajar yang tinggi akan lebih terlibat aktif selama proses pembelajaran dan berhasil dalam belajar. Salah satu model pembelajaran yang inovatif yang dapat diterapkan yaitu, Two Stay Two Stray karena model pembelajaran Two Stay Two Stray dapat memfasilitasi siswa untuk berperan aktif dan berperilaku terbuka terhadap teman dalam pembelajaran sehingga mampu menambah wawasan siswa secara luas dan dapat berpengaruh pada hasil belajar. Hal tersebut sesuai dengan pendapat Spencer Kagan dalam Alfitri dan Setiani (2018:2) mengemukakan bahwa model pembelajaran Two Stay Two Stray adalah suatu model pembelajaran yang memberi kesempatan kepada anggota kelompok untuk membagi hasil dan informasi dengan anggota kelompok lainnya dengan cara saling mengunjungi atau bertamu antar kelompok. Hasil belajar siswa juga sangat dipengaruhi oleh semangat dan motivasi belajar peserta didik sehingga penggunaan model Two Stay Two Stray dapat digunakan guru sebagai tidakan tertentu untuk meningkatkan hasil belajar siswa sehingga siswa juga mau terlibat aktif dan semangat dalam proses pembelajaran yang berlangsung.

Keberhasilan dalam penelitian ini dapat menunjukkan bahwa model pembelajaran Two Stay Two Stray dapat meningkatkan hasil belajar IPA siswa sekolah dasar melalui metode penelitian Meta Analisis. Namun, 
penelitian ini mempunyai kelemahan yaitu sumber penelitian yang relevan yang digunakan oleh penulis cukup terbatas dikarenakan penulis mengalami kesulitan dalam mencari sumber penelitian yang berkaitan dengan hasil belajar IPA, serta hasil temuan bergantung pada kemampuan dan pengalaman penulis, unsur subjektivitas lebih tinggi sehingga mempengaruhi ojektivitas hasil temuan. Sedangkan kelebihan dari penelitian ini, penulis memilih sumber dengan jenis penelitian yang relevan, karena menganalisis jenis penelitian yang sama, menyebabkan data deskriptifnya lebih detail dan mendalam sehingga apabila disajikan dalam bentuk laporan dapat dibuat secara sistematis, jelas dan terperinci.

\section{Simpulan}

Hasil penelitian meta analisis, ditarik kesimpulan bahwa hasil belajar IPA siswa di sekolah dasar dapat ditingkatkan dengan menerapkan model pembelajaran Two Stay Two Stray. Pernyataan tersebut dapat ditunjukkan berdasarkan hasil analisis adanya peningkatan hasil belajar siswa mulai dari yang terendah $\quad 0,080 \%$ sampai yang tertinggi 51,24\%. Rata-rata skor sebelum tindakan yaitu 36,11. Sedangkan rata-rata skor setelah tindakan yaitu 46,67. Selisih rata-rata skor sebelum dan sesudah tindakan yaitu 10,56. Dari analisis yang telah dilakukan dapat dilihat gain\% yaitu 25,47\%. Dengan demikian peneliti menarik kesimpulan bahwa model pembelajaran Two Stay Two Stray dapat meningkatkan hasil belajar IPA siswa sekolah dasar.

\section{Daftar Pustaka}

Alfitri, P. A. A., \& Setiani, A. 2018. Model Two Stay Two Stray Sebagai Alternatif Model Pembelajaran untuk Meningkatkan Hasil Belajar Matematika Siswa di Sekolah. Jurnal neliti Vol. 2 No. 1.

Ahmad Susanto. 2013. Teori Belajar dan Pembelajaran di Sekolah Dasar. Jakarta: PT Kharisma Putra Utama.

Amanun, Khoirul. 2018. Keefektifan Model Two Stay Two Stray terhadap Hasil Belajar pada Mata Pembelajaran IPA Siswa Kelas V SD. Jurnal Sekolah (JS) Vol. 2 No. 3, Hal 160-165.

Azizah, K. N., \& Mintohari. 2015. Pengaruh Model Pembelajaran Kooperatif Two Stay Two Stray terhadap Hasil Belajar Siswa di 
Sekolah Dasar. Jurnal PGSD Vol. 03 No. 02, Hal 302-310.

Dewi, N. L. P. Y., Putra, D. B., \& Abadi, I. B. 2014. Model TSTS Berbantuan Peta Konsep Berpengaruh terhadap Hasil Belajar IPA Kelas V. Jurnal Mimbar PGSD Universitas Pendidikan Ganesha Jurusan PGSD Vol. 2 No. 1.

Dewi, N. W. E. P., Margunayasa, I. G., \& Kusmariyatni, N. N. 2018. Pengaruh Model Pembelajaran Kooperatif Two Stay Two Stray terhadap Hasil Belajar IPA. Jurnal Pendidikan dan Pembelajaran IPA Indonesia Vol. 8 No. 2, Hal 122-129.

Diarsa, I. P., Murda, I. N., \& Dharmayanti, P. A. 2017. Pengaruh Model Pembelajaran Two Stay Two Stray Berbantuan Media Visual terhadap Hasil Belajar IPA Siswa. Jurnal Mimbar PGSD Universitas Pendidikan Ganesha Jurusan PGSD Vol. 5 No. 2, Hal 1-11.

Dumaini, N. K., Suarjana, I. M., \& Dibia, I. K. 2019. Pengaruh Model Pembelajaran TSTS terhadap Hasil Belajar IPA. Journal of education Vol.3 No.2, Hal 103110.

Fitrianingrum, W. S., \& Zuhdi, U. 2018. Pengaruh Model Pembelajaran TSTS terhadap Hasil Belajar IPA pada Siswa Kelas IV. JPGSD Vol.6 No.6, Hal 945-953.
Giantri, N. K. Y., Wiyasa, I. K. N., \& Suadnyana, I. N. 2017. Pengaruh Model Pembelajaran Kooperatif Tipe Two Stay Two Stray terhadap Hasil Belajar IPA Kelas IV. Mimbar PGSD Vol. 5 No. 2, Hal 1-9.

Harta, J., Dharsana, I. K., \& Renda, N. T. 2019. Pengaruh Model TSTS Melalui Lesson Study terhadap Hasil Belajar IPA. Jurnal Mimbar Ilmu Vol. 24 No. 1, Hal 95-103.

Iskandar dan Mansyur. 2017. Meta Analisis Karya Ilmiah Mahasiswa Penelitian dan Evaluasi Pendidikan. Jurnal Scientific Pinisi Vol. 3 No. 1 April 2017.

Juniantari, I. G., \& Kusmariyatni, N. N. 2019. Pengaruh Model Pembelajaran Kooperatif TSTS Berbantuan Mind Mapping terhadap Hasil Belajar IPA. Jurnal Ilmiah Sekolah Dasar Vol. 3 No. 3, Hal 371-377.

Karlina, C. F., Dharsana, I. K., \& Kusmariyatni, N. 2017. Pembelajaran Kooperatif Tipe TSTS Berbantuan Peta Pikiran untuk Meningkatkan Hasil Belajar IPA melalui Lesson Study. Mimbar PGSD Vol. 5 No. 2, Hal 1-10.

Kumape, Sitilin. 2015. Pengaruh Penerapan Model Pembelajaran Kooperatif Tipe Two Stay Two Stray terhadap Aktivitas dan Hasil Belajar Siswa Tentang IPA di Kelas VI SD Inpres Palupi. 
Jurnal Kreatif Tadulako Online Vol. 4 No. 4, Hal 351-361.

Prasatya, L. K. L., Murda, I. N., \& Arini, N. W. 2017. Pengaruh Model Pembelajaran TSTS Berbasis Masalah terhadap Hasil Belajar IPA Siswa Kelas V. Mimbar PGSD Vol. 5 No. 2, Hal 1-10.

Rediarta, I. W., Sudarma, I. K., \& Murda, I. N. 2014. Pengaruh Model Kooperatif TSTS terhadap Hasil Belajar IPA. Jurnal PGSD Vol.2 No. 1.
Sidabutar, G. S., \& Dharsana, I. K. 2018. Pengaruh Model Pembelajaran Kooperatif Tipe TSTS melalui Lesson Study terhadap Hasil Belajar IPA. Mimbar PGSD Undiksha Vol. 6 No. 2, Hal 103108.

Trianto. 2010.Mendesain model pembelajaran inovatifprogresif.Surabaya: Kencana Prenada Media Group.

Zairmi, U., Fitria, Y., \& Amini, R. 2019. Penggunaan Model Pembelajaran Two Stay Two Stray dalam Pembelajaran IPA di Sekolah Dasar. Jurnal Basicedu Vol. 3 No. 4, Hal 1031-1037 